\title{
Causes of Dropouts at Cardinal Rugambwa Memorial University College, Tanzania
}

\author{
Frowin Mlengule ${ }^{1}$ \\ ${ }^{1}$ Cardinal Rugambwa Memorial University College, Tanzania
}

\begin{abstract}
This study was conducted to verify, using the case of Cardinal Rugambwa Memorial University College, the widely held view that financial challenges are significant determinants of student dropouts in private universities in Tanzania. The study was conducted following a case study design. The findings were that with exception of tuition fees, financial constraints are significant causes of students' failure to complete their study programmes. Other reasons that were found to be substantial causes of drop outs in this University College are related to students' domestic and private reasons that include going to institutions near the home to take care of or being near their spouses. Administration related bottlenecks and gaps in guidance and counselling were also found to lead to dropout. Policy recommendations and areas for future research are identified.
\end{abstract}

Keywords: Liberalisation; Student affairs; Funding.

\section{$1 \quad$ Introduction}

When higher education is effectively planned and administered, it offers remarkable private and public dividends. On one hand, it bears potential to the beneficiary to acquire meaningful empowerment and therefore, emancipation. On the other hand, society benefits through higher education training and teaching activities, as well as through enhanced research interventions to augment lifestyles (Psachalopoulos \& Woodhall, 1985). Therefore, demand for higher education has been expanding, notably on the African continent and higher educational institutions have responded by enrolling massive numbers of students each year. For example, between 2000 and 2006, Africa's higher education student population increased by 55 percent from about 6 to 9.3 million (World Bank, 2010). 
Nonetheless, the expansion in student enrolments into higher education has allegedly been constrained by issues of sustainable financing (Court, 1999). The World Bank Report (2010) restated that while Africa has maintained its public investment in higher education over the last two decades - allocating, though paltry, around 0.8 per cent of its gross domestic product (GDP), and more or less 20 percent of its present public expenditure on education to this sector, the cumulative enrolment growth in higher education has more than tripled, from 3 million in 1991 to over 10 million in 2006. This is an average growth rate of about 16 percent. Worryingly, public resources allocated to current expenditure in the sector of higher education, on average, has only doubled (an annual average rate of at least 6 percent) - causing extensive mismatch between social demand for higher education and the financial or supportive resources (World Bank, 2010). As mitigating measures to address the over-constrained public expenditure on higher education, African governments entrenched liberal reforms to commercialise and privatise for greater democratised access to higher education institutions. The intention was clear from onset: to ascertain raised quality of service delivery and augmentation of private as well as social progress and development (Mamdani, 2007; Court, 1999).

In Tanzania, liberal reforms in the higher education sector were embraced in 1990 s to attend to the rising social and private demand for higher education, in the situation where scarcity of public resources was becoming realistically very perennial, after a period of totally free education provided by the Government. In 1992 the government of Tanzania introduced a cost-sharing policy that, in essence, expected beneficiaries to gradually contribute funds to meet the cost of training and education. The policy was to be achievable in three major stages, starting in 1992 when the first phase was unveiled. During this stage, students were henceforth required to meet transportation and academic, as well as administrative costs. The second phase was then flagged off in 1994. In this, living expenses (mostly food and housing), were meant to be covered by the students themselves. Nevertheless, those who could not afford the costs, repayable loans were henceforth made available something still standing. In the last phase, starting with the year 2005 to date, the students and or the benefitting households were meant to contribute to their overall education costs (Ishengoma, 2008; Dachi, 2018).

In ultimate, all is well for those students who are lucky to get onto the government loan scheme; nonetheless, "When it comes to the question of who benefits from the process of financing higher education, one can conclude that, it is the upper class because the loans scheme especially from the government, as the main financier of education, is being implanted without taking into consideration other issues like; the level of income of the families' (Dachi, 2018; Omari, 1994). This implicitly means that the poorest of the poor normally 
miss out. To make matters worth these have also been perceived as the ones who have limited access to the vital information relating to the loan possibility. Even so, what is distressing is the fact that those that attempt to get enrolled into higher institutions of their choice via hard earned private financial mobilizations; often drop out of the formal higher education pipeline - the allegation that requires closer and systematic scrutiny.

In Cardinal Rugambwa Memorial University College (CARUMUCO), for example, in academic year 2016/2017 slightly over 50 students out of 243 (21 per cent) new enrolments for this period dropped out of the cherished education before the end of their second semester allegedly as a result of constrained financial realisation, something that left many in management and administration greatly amazed, albeit, with unsatisfactory explanations. At the moment (ceteris paribus) it is not yet clear whether it is really the financial constraints that could be responsible for this paucity on this and possibly on the other former cohorts. Empirical investigations to get reliable answers to the predicament are called for, thus if Tanzania is to remain on the rail of its development Agenda of 2025.

Five objectives are set to achieve the purpose of the study.

1. To examine whether students' failure to complete their studies is caused by failure to get money for transport to and from the College.

2. To investigate whether student's failure to complete their studies is caused by failure to get tuition fees.

3. To investigate whether students' failure to complete their studies is influenced by failure to get administrative fees.

4. To establish whether students' failure to complete their studies is caused by failure to get money for food.

5. To establish whether students' failure to complete their studies is due to failure to get housing rent.

6. To establish the other causes of the dropout rates at CARUMUCO.

\section{Theoretical and Conceptual Orientation}

This study was premised on Ernest Hemingway Iceberg Theory (IBT) which implicitly posits that always any occurring phenomena/ observations are but just a very limited amount of reality (the tip of something else which is normally very gigantic). Connotatively, whatever is available or visible about a situation or phenomenon is normally a symptomatic representation of something else. The theory gets its name from the reality that only about 10 percent of an iceberg's mass is seen outside while the rest (about 90 percent) of it is unseen; hidden or covered deep down in water (Figure 1). 


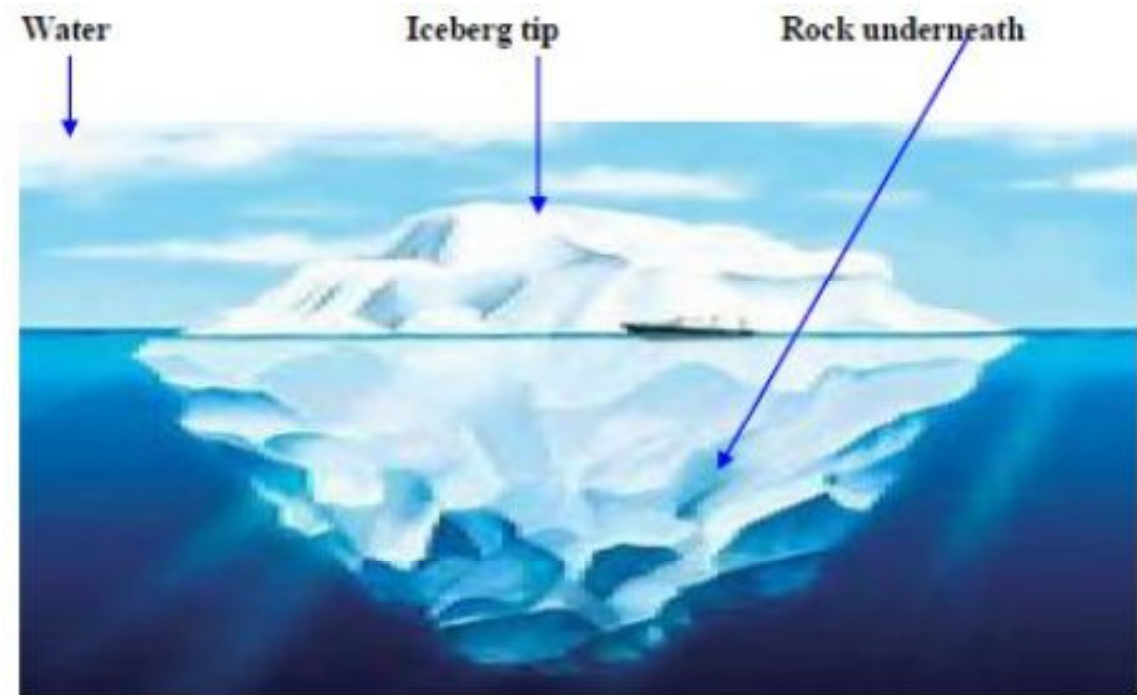

Figure 1: Pictorial Representation of IBT

Source: www.businessdictionary.com/definition/iceberg-principle.html

It is because of this that successful sailors are usually fearful of passing near or through the iceberg, otherwise their boats can be destroyed by the rock underneath. In Economics of Education, Organisational Behaviour and Management, it is always essential for managers not to take things for granted as most of the organisational phenomena are mere symptoms. Prudent organisational managers ought to uncover the causes underlying any organisational behaviours. It is with this understanding that this study undertook to scrutinise the commonly held view that financial challenges are the antecedents of the dropouts at CARUMUCO.

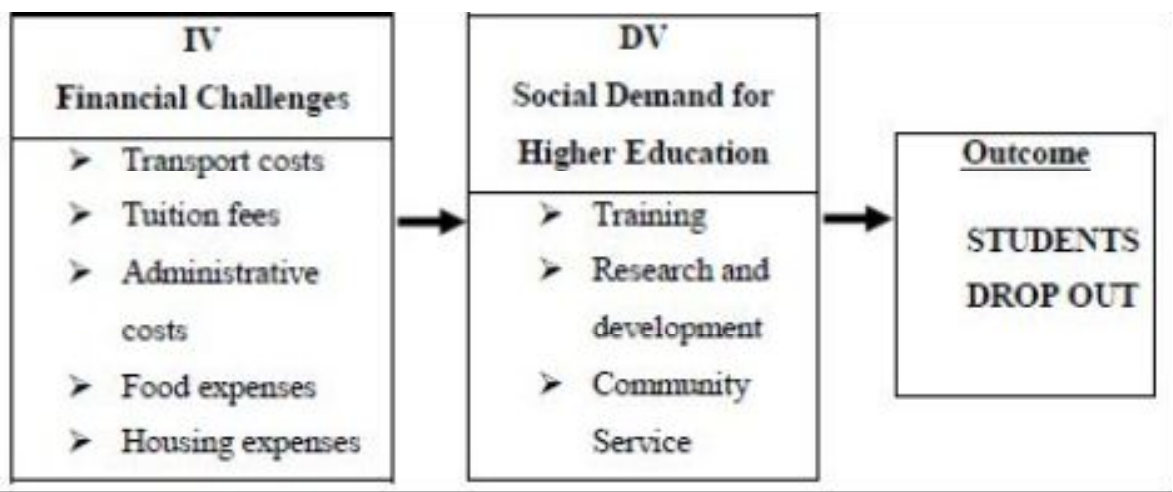

Figure 2: Conceptual Framework

Source: Adapted from Ishengoma (2008) and Dachi (2000). 
Basing on IBT (Figure 1), ice tips represented ineffective social demand for desired training and research skills, manifested in form of drop-out of students in CARUMUCO. Yet, behind this symptomatic behaviour (the ice tip), there are possible hidden causes; the rocks, otherwise conceived by the study as the financial challenges (independent variable) with the underpinnings of: transport costs, tuition fees, administrative costs, food expenses and housing expenses, inter alia, that allegedly debar social aspirations for University education (Figure, 2).

In Figure 2, financial challenges (the study independent variable), according to Ishengoma (2004), were underpinned by transport, tuition and administrative costs. Others were housing and food expenditures (Figure: 2). The dependent variable of the proposed study was perceived as social demand, underpinned by training and research - inter alia, as adapted from Tanzania Commission for Universities (2017). The researcher assumed that social demand for University education ought to be accompanied by ability to meet costs involved in order to realise expected outcomes. Nevertheless, in the case were such demand is ineffective, diverse consequences really manifest. Drop outs in the study were perceived as consequences of ineffective social demand for higher education, where clients fail to raise the required funds, therefore.

\section{$3 \quad$ Methodology}

Using application forms, registers and attendance lists for academic year 20162017, the researcher established the addresses of the 64 flesh students who dropped out of the University College during the course of the year. Categorical (Yes/No) and qualitative data were collected and recorded from 48 locatable and willing respondents, using five structured and open-ended telephone conversation/interview items (Table 1); all developed from the research hypotheses $\left(\mathrm{H}_{1}\right)$ :

1. Students' failure to continue with studies at CARUMUCO is caused by their failure to get tuition fees.

2. Students' failure to continue with studies at CARUMUCO is influenced by their failure to get administrative fees.

3. Students' failure to continue with studies at CARUMUCO is caused by their failure to get money for food.

4. Students' failure to continue with studies at CARUMUCO is due to their failure to get housing rent.

5. Students' failure to continue with studies at CARUMUCO is caused by their failure to get transport to and from the University College.

6. Student may have other reasons leading to their failure to continue with studies at CARUMUCO. 
Table 1: Structured Interview Guide

\begin{tabular}{|c|c|c|c|}
\hline Item & Statement & True & Not true \\
\hline 1 & I dropped out of my program due to failure to get tuition fees & & \\
\hline 2 & I dropped out of my program due to failure to get administrative fees & & \\
\hline 3 & I dropped out of my program due to failure to get money for food & & \\
\hline 4 & I dropped out of my program due to failure to get housing rent & & \\
\hline 5 & $\begin{array}{l}\text { I dropped out of my program due to failure to get transport money to } \\
\text { and from the CARUMUCO }\end{array}$ & & \\
\hline 6 & Please specify any other reason(s) for dropping out of your program & & \\
\hline
\end{tabular}

Analysis of descriptive data was done using percentages, while data on hypotheses was analysed with calculations of chi square goodness - of - fit Test, using the model: $\chi^{2}$ obs $=\sum\left[\left(f_{o}-f_{e}\right)^{2} \div f_{e}\right]$ at appropriate significance level $(p=0.05)$ and degree of freedom $(d f=k-1)$, where ' $k$ ' stands for number of response categories, according to Amin (2005). In this analysis ' $\mathrm{k}$ ' stood for 'True' and 'Not true'. Then $\left(f_{o}-f_{e}\right)$ referred to the difference between observed and expected frequencies.

\section{$4 \quad$ Findings and Discussion}

The findings are summarised in Table 2 .

Table 2: Descriptive and inferential statistics

\begin{tabular}{|c|c|c|c|c|c|c|}
\hline Item & True $\left(f_{0}\right)$ & Not true $\left(f_{0}\right)$ & $\mathrm{N}$ & $f_{e}$ & $\chi^{2}$ obs & $\begin{array}{l}\chi^{2} c v: \\
d f=1 \\
P=0.05\end{array}$ \\
\hline $\begin{array}{l}\text { Failure to get tuition } \\
\text { fees }\end{array}$ & $29(63 \%)$ & $17(36.96 \%)$ & 46 & 23 & 3.13 & $\begin{array}{l}3.841>\left(\chi^{2} \text { obs }\right) \\
\text { Insignificant }\end{array}$ \\
\hline $\begin{array}{l}\text { Failure to get } \\
\text { administrative fees }\end{array}$ & $32(69.6 \%)$ & $14(30.43 \%)$ & 46 & 23 & 7.044 & $\begin{array}{l}3.841<\left(\chi^{2} \text { obs }\right) \\
\text { Significant }\end{array}$ \\
\hline $\begin{array}{l}\text { Failure to get money for } \\
\text { food }\end{array}$ & $35(76.1 \%)$ & $11(23.91 \%)$ & 46 & 23 & 12.552 & $\begin{array}{l}3.841<\left(\chi^{2} \text { obs }\right) \\
\text { Significant }\end{array}$ \\
\hline $\begin{array}{l}\text { Failure to get housing } \\
\text { rent }\end{array}$ & $16(34.8 \%)$ & $30(65.22 \%)$ & 46 & 23 & 4.260 & $\begin{array}{l}3.841<\left(\chi^{2} \text { obs }\right) \\
\text { Significant }\end{array}$ \\
\hline $\begin{array}{l}\text { Failure to get transport } \\
\text { money to/fro }\end{array}$ & $03(6.52 \%)$ & $43(93.48 \%)$ & 46 & 23 & 34.782 & $\begin{array}{l}3.841<\left(\chi^{2} \text { obs }\right) \\
\text { Significant }\end{array}$ \\
\hline
\end{tabular}

Source: CARUMUCO Admission Records (2016/17)

Table 2, shows that over (29)63.4\% out of 46 respondents opined that they dropped out of CARUMUCO due to failure to get tuition fees. Nevertheless $17(36.96 \%)$ out of 46 respondents, did not agree with the set notion. This is a relatively big percentage signifying that there could be some other reasons that are responsible for this other than the issue of tuition fees only, almost 40 per 
cent drop outs some of which are catered fore in the proceeding hypotheses. This phenomenon prompted the researcher to go ahead to calculate and analyse inferential data on; $\mathrm{H}_{0}$ : The student's failure to continue with studies at CARUMUCO is not caused by one's failure to get tuition fees. This was tested using the following model:

$\chi^{2}$ obs $=\sum\left[\left(f_{o}-f_{e}\right)^{2} \div f_{e}\right]$, at appropriate significance level $(p=0.05)$ and degree of freedom $(d f=k-1)$, where ' $k$ ' stands for number of response categories, was applied, according to Amin (2005). It was found out that $\chi^{2}{ }_{\mathrm{ob}}=3.13$ and this was less than

$\chi^{2}{ }_{\mathrm{cv}}$, which was (3.841: $d f=1$ and $p=0.05$ ), implying that results (claims) were statistically not significant. This led to the retention of the null hypothesis $\left(\mathrm{H}_{\mathrm{O}}\right)$, as the research hypothesis $\left(\mathrm{H}_{1}\right)$ was dropped. It was therefore concluded that the student's failure to continue with studies at CARUMUCO is not mainly caused by one's failure to get tuition fees. This is really possible because according to the University Bursar students are normally given ample time in which to clear the University tuition fees. This is seen as a democratic imperative assisting even those students that happen to come from poor families or households.

It was also found out that a good number of students drop out of CARUMUCO due to failure to get sufficient and timely funds to meet administrative costs (about 70\%); and failure to get money for food during student times at the University College (76\%). During the conversations with all the respondents it was learnt that although the administrative costs are not substantially and prohibitively high as compared to tuition fees which is in millions, these costs are usually needed by University authority at once. Tuition fees are usually paid on a $P R N$ (whenever convenient) basis. When a chi square goodness - of - fit Test $\left(\chi^{2}\right)$ test, was applied with the statistical model: $\chi^{2}$ obs $=$ $\sum\left[\left(f_{o}-f_{e}\right)^{2} \div f_{e}\right]$ as data were both numerical and categorical (Amin, 2005), it was discovered that the claims on, "failure to get sufficient and timely funds to meet administrative costs; and failure to get money for food during student times at the University College", were statistically significant as $\left(\chi^{2}{ }_{\text {obs }}>\chi^{2}\right.$ cv) at $(p=0.05$ and $d f=1)$. In the case of the former,

$\chi_{o b s}^{2}=7.044$ and $\chi^{2}$ obs $=3.841$, respectively. Furthermore, in the case of the latter, $\chi^{2}$ obs $=12.552$ and $\chi^{2}$ obs $=3.841$. This led to the rejection of the null hypothesis $\left(\mathrm{H}_{\mathrm{O}}\right)$ and retention of the research hypothesis $\left(\mathrm{H}_{1}\right)$. It was therefore established that both 'ability to get and pay administrative costs' and ability to get money for food while at the University College, are unfortunate issues that detour students either from entering or continuing with studies at CARUMUCO.

However, most of the respondents did not agree with the interview statements that one dropped out of CARUMUCO due to "failure to get housing 
rent and transport money to/fro CARUMUCO". Over 65 per cent and 93 percent respectively did so (Table 2). This probably meant that transport and accommodation costs in the country could be substantially high and prohibitive. To confirm whether these claims $\left(\mathrm{H}_{0} 4 \& 5\right)$ were really significant, it was found out via the chi square tests at the appropriate significance levels and degree of freedom that although the respondents declined to uphold the 'True' stand on the set notions, their assertion on the "Not true" side were highly substantial or significant because $\left(\chi_{o b s}^{2}>\chi^{2}\right.$ cv $)$, that is, $\left(\chi^{2}\right.$ obs $=4.260$ and $34.384>\chi_{c \mathrm{cv}}^{2}=$ 3.841) - Table 2.

The 46 respondents were further asked to give other reasons outside those in the structured category. The most outstanding responses are summarised in Table 3.

Table 3: Summary of Reasons cited for Dropping Out

\begin{tabular}{lllll}
\hline Item & Freq. & Male & Female & Remark \\
\hline Discovered that College life was not interesting & $8(17.4 \%)$ & 5 & 3 & Low \\
Administration was not approachable for needed help & $2(4.3 \%)$ & 1 & 1 & Negligible \\
What I expected to learn was not forthcoming & $3(6.5 \%)$ & 3 & 0 & Negligible \\
I Joined another institution near our home area & $26(56.5 \%)$ & 16 & 16 & Fairly High \\
I got domestic problems & $25(54.3 \%)$ & 17 & 8 & Fairly High \\
I preferred employment to schooling & $7(15.2 \%)$ & 5 & 2 & Low \\
I got problems with some friends & $9(19.6 \%)$ & 3 & 6 & Low \\
I was disgusted with the methods used in teaching & $1(2.2 \%)$ & 1 & 0 & Negligible \\
\hline
\end{tabular}

On this qualitative - open ended notion, the most outstanding reason given as the possible precursor to the dropouts in CARUMUCO was: 'I joined another institution near our home area'; about 60\% (16 female and 16 male) of the 46 respondents, said so in the interviews. Substantially about 50 per cent of these gave the reason that they were married and wanted to be near their families. Another reason advanced was 'I got domestic problems'- about 54\%, most of these being male students (17 out of 25). Incidentally, these were also giving the reason related to marriage issues. Other reasons given (though not substantial) were, respectively: 'I got problems with some friends - 19.6\%; Discovered that College life was not interesting - 17.4\%; I preferred employment to schooling $-15.2 \%$. Other responses were just negligible (Table $3)$.

In view of the findings and in the context of privatised and commercialized service delivery in CARUMUCO, the following recommendations are proposed:

1. The University College should endeavour to put in place alternative funding sources to assist the students that can't afford. This could be (if and when possible) in form of: 
a) Provision of free place provisions to those students joining the University College with exceptional skills e.g. in games and sports. Their financial support and maintenance can be enabled through enhanced grants and endowments from motivated friendly partners such as the mother church, local and international fraternities, local administrative agencies, as well as relevant multinational and international agencies

b) Secondly, the University can roll out feasible commercial and development projects e.g. in agriculture, carpentry, leisure and recreational activities e. g. in music, dance and drama - where needy students can become involved, with pay, to meet college obligations and requirements.

c) Conversely, the College can bench mark with those succeeding higher educational institutions in student retention, particularly private Universities. It is hoped this will augment the University think tank to plan for more feasible measures in this area, thus becoming more effective and efficient.

2. The governance and management of CARUMUCO should put in place a strong counselling and guidance department to render timely advice to the students in matters that are claimed to lead the students' dropout from the formal educational pipeline.

\section{References}

Amin, M. (2005). Social science research: conception, methodology and analysis. Kampala: Makerere University Printery.

Court, D. (1999). Financing Higher Education in Africa: Makerere, the Quiet Revolution. Washington DC.: The World Bank and the Rockefeller Foundation.

Dachi, A.H. (2018). Student loans in higher education finance in Tanzania: a delusion, or a hidden benevolent grant scheme? Retrieved from http://stiiep.iiep-unesco.org/cgibin/wwwi32.exe/[in=epidoc1.in]/?t2000=013628/(100).

Ishengoma, J.M. (2008). Financing Public Higher Education in Tanzania: Towards a New Model and Implications for Development and Retention of the Next Generation of Academics. Faculty of education, UDSM.

Ishengoma, J.M. (2004). Cost sharing and Participation in Higher Education in Sub-Saharan Africa: The case of Tanzania. Doctoral dissertation. State University of New York at Buffalo.

Mamdani, M (2007). Scholars in the market place: The dilemmas of Neoliberal reforms at Makerere University, 1989-2005. Kampala: Fountain Publishers. 
Psachalopoulos, G., Woodhall M. (1985). Education for Development. Oxford: Oxford University Press.

Tanzania Commission for Universities (2017). Tanzania Commission for Universities Report: Dar es Salaam: Author. 